\title{
FILSAFAT ILMU: SUATU TINJAUAN PENGERTIAN DAN OBJEK DALAM FILSAFAT PENGETAHUAN
}

\author{
Umar \\ Institut Agama Islam (IAI) Muhammadiyah Bima \\ Email: laodeumarpgmi@gmail.com
}

\begin{abstract}
Abstrak
Posisi filsafat dan ilmu meskipun pada tinjauan historisnya sukar dipisahkan karena filsafat yang merupakan induk dari segala ilmu pengetahuan, akan tetapi dalam perkembangan antara filsafat dan ilmu perlu dibedakan sacara definisi. Pemetaan definisi antara filsafat dan ilmu bukan berarti mecoba untuk memalingkan keberadaan filsafat sebagi induk dari segala pengetahuan. Melainkan pemetaaan definisi ilmu dan filsafat dimaksudkan untuk menegaskan kembali terkait eksistensi filsafat dan ilmu. Dalam perkembangan tradisi filsafat dan ilmu pengetahuan di dunia Barat mengalami perkembangan pesat sejak terlepas dari filsafat skolatik yang didominasi oleh elit gereja. Masa ini dimulai dengan kelahiran filsafat Barat modern dalam renaisans. Sementara itu, filasafat dan ilmu pengetahuan dalam Islam tetap berada dalam dominasi pemikiran salaf dengan tradisi skolatiknya sendiri. Dua tradisi besar filasafat dan ilmu pengetahuan ini mengambil jalanya sendiri, walaupun keduanya tetap berada dalam panduan tradisi filsafat yang sama yaitu filsafat Yunani.
\end{abstract}

Kata Kunci: Pengertian, Filsafat, Ilmu.

\section{PENDAHULUAN}

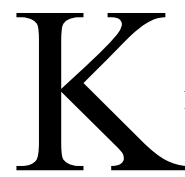

onteks teologi ilmu pengetahuanpun merupakan ciri yang membedakan antara makhluk manusia dengan makhluk membuat kondisi "kosmik" malaikat terguncang, terjadi kondisi "chaotik" dengan pertanyaan mendasar malaikat: "Mengapa engkau Engkau hendak menjadikan di Bumi itu orang-orang yang akan membuat kerusakan padanya dan menumpahkan darah, pada hal kami senantiasa bertasbih dengan memuji Engkau dan mensucikan Engkau?" Tuhan menunjukan bahwa rencanaNya tidak keliru dengan membuktikan bahwa ciptaanNya yang berupa Adam sebagai simbolisasi manusia memiliki kelebihan dibandingkan makhluk lain yakni berilmu, sehingga semua tunduk kecuali Iblis (Charris Zubair, 2002). 
Dalam persepektif lain, konstruksi pengetahuan manusia bila dicermati tumbuh dan berkembang disemua sistem budaya masyarakat di dunia Islam dan Barat. Di awali dari sebuah tradisi filsafat yang tumbuh dan berkembang sebelum nabi Isa as lahir pada tahun pertama masehi. Tradisi yang lebih dikenal dengan tradisi Yunani atau Helenis, yang bisa diduga berkaitan dengan tradisi kenabian Musa as dengan Tauratnya, dan kenabian Daud as dengan Zaburnya. Tradisi filsafat dan ilmu pengetahuan di dunia Barat mengalami perkembangan pesat sejak terlepas dari filsafat skolatik yang didominasi oleh elit gereja. Masa ini dimulai dengan kelahiran filsafat Barat modern dalam renaisans. Sementara itu, filasafat dan ilmu pengetahuan dalam Islam tetap berada dalam dominasi pemikiran salaf dengan tradisi skolatiknya sendiri. Dua tradisi besar filasafat dan ilmu pengetahuan ini mengambil jalanya sendiri, walaupun keduanya tetap berada dalam panduan tradisi filsafat yang sama, yaitu filsafat Yunani (Sabri, 2009).

Perkembangan selanjutnya, manusia seringkali menganggap ilmu itu sebagai satu kesatuan di luar dan di atas waktu, yang terdiri atas himpunan-himpunan, petunjuk-petunjuk dan pernyataan-pernyataan. Ketika pandangan "filsafat abadi" disisihkan oleh pandangan historis, maka ilmu mulai mengambil tempat yang kosong itu. Padangan tersebut keliru, karena justru selama dasawarsa terakhir ini makin menonjol kenyataan bahwa ilmu tidak abadi melainkan berubah. Dalam arti yang sederhana bahwa tidak ada ilmu yang selesai. Para ilmuwan selalu dapat mengembangkan ilmu lebih lanjut. Ilmu bukan ibarat sebuah rumah dengan dasar abadi sepanjang sejarah hanya dilengakpi dengan tingkattingkat baru, bahkan strukur ilmu yang disebut pokok ilmu mengalami perubahan (C.A.Van Peursen, 1989).

Seiring dengan adanya konsepsi tentang relatifnya sebuah ilmu pengetahuan, seorang filsuf terkemuka Erenst Cassirer menjelaskan bahwa pandangan kebudayaan bukan suatu yang statis atau stagnan, melainkan memiliki dinamika yang khas. Dinamika itu terjadi karena adanya pertentangan antara kecenderungan untuk melestarikan tapi serentak bersama juga adanya kehendak untuk maju. Di antara kedua daya yang bertentangan itu ternyata ilmu merupakan daya yang paling 
progresif dalam keseluruhan spektrum kebudayaan (Conny Setiawan, 2005). Ilmu pula yang merupakan penjelmaan kesanggupan transendensi manusia melalui berbagai fungsi yang dimilikinya, seperti berfikir, bernalar, berbahasa bahkan melalui imajinasi dan fantasinya. Ilmu telah membawa manusia mencapai berbagai keunggulan dalam penjelajahannya yang tak hirau terhadap berbagi pembatasan yang memasungnya pengembangan kesanggupannya untuk melakukan trasendensi ikhtiar tentang adanya dunia kemungkinan. Ikhitiar demi ikhtiar menjadikan manusia ilmu sebagai sejarah yang menentukan perkembangan peradaban manusia. Perkembangan ilmu menjadikan dunia manusia sebagai kenyataan yang lebih banyak menwarkan pilihan ketimbang keharusan (Conny Setiawan, 2005).

Dari beberapa uraian di atas, kaitannya dengan persoalan ilmu dan pengetahuan, paling tidak dalam pandangan penulis terdapat tiga hal yang mendasar yang dapat dipahami, antara lain: Pertama, secara historiografi perkembangan ilmu dan pengetahuan manusia, sejatinya sudah berlangsung sejak lama dan menjadi dasar penciptaan manusia. Kedua, konsepsi tentang relatifnya ilmu pengetahuan yang memberikan penegasan bahwa dalam perkembanganya senantiasa berubah, dan tidak ada kemustahilan bahwa pandangan tentang ilmu pengetahuan akan berbeda bahkan bisa bertentangan satu dengan yang lainnya.

Perkembangan ilmu pengetahuan sekaligus menjadi parameter yang dapat membedakan pembentukan peradaban manusia setiap zamanya. Dalam artian, peradaban manusia terbentuk berdasarkan tingkat pengetahuannya. Perkembangan selanjutnya, ilmu tebagi menjadi bebrapa disiplin ilmu, yang membutuhkan pendekatan, sifat, objek, tujuan dan ukuran yang berbeda antra disiplin ilmu yang satu dengan yang lainya. Pada gilirannya, cabang ilmu menjadi subur dengan segala variasinya. Namun, tidak dapat dipungkiri bahwa ilmu yang terspealisasi itu semakin manambah sekat antara disiplin ilmu denga disiplin ilmu yang lain. Tidak hanya sekedar sekat antar disiplin ilmu dan organisasi ilmu, tetapi yang terjadi adalah terpisahnya ilmu dengan nilai luhur ilmu yang pada dasarnya untuk menyejahterakan umat manusia, bahkan tidak 
mustahil terjadi, ilmu menjadi bencana bagi kehidupan umat manusia, seperti pemanasan global dan dehumanisasi (Amsal Bakhtiar, 2013).

Terlepas problematika perkembangan ilmu pengetahuan yang tak terkendali, dan cenderung menjauhi nilai-nilai luhur dari tujuan ilmu pengetahuan. Tentunya perkembangan disiplin ilmu pengetahuan yang beragam itu, didasari dari objek kajian filsafat ilmu pengetahuan yang memilki karateristik yang begitu kompleks, sehingga menimbul multitafsir bagi setiap orang atau manusia yang mencoba untuk menyelami makna-makna pada obyek-obyek kajian tesebut. Berangkat dari gambaran teoritis di atas, penulis mencoba menguraikan satu tulisan yang berkenaan dengan topik bahasan "Filsafat Ilmu: Suatu Tinjauan Pengertian Dan Objek Dalam Filsafat Pengetahuan" pada batasanbatasan tertentu, sebagai instrumen dialog. Besar harapan pembahasan makalah ini, dapat memberikan sumbangsi pengetahuan, terkhusus bagi penulis dan insan-insan yang peduli akan pengetahuan tertuma yang berkaitan filsafat ilmu.

\section{Batasan Etimologis Filsafat dan Ilmu}

Pada zaman Yunani kuno, filsafat dangan ilmu sukar untuk dipisahkan. Pembuktian emperik kurang mendapat perhatian dan metode ilmiah tampaknya belum berkembang pada saat itu, sehingga sukar untuk membedakan ilmu dan filsafat. Sedikit demi sedikit, dengan makin berkembangnya penalaran dan metode ilmiah, dengan makin kuatnya dan makin dihargainya pembuktian emperik, dan seiring dengan itu, meluasnya penggunaan instrumen penelitian, satu per satu cabangcabang ilmu mulai melepaskan diri dari filsafat. Menurut Conny Setiawan (2005) ketika ilmu masih meruapakn bagian dari filsafat, definisi ilmu masih bergantung pada sistem filsafat yang dianut, sedangkan sewaktu posisi ilmu bebas dan lebih mandiri, maka definisi ilmu cenderung didasarkan pada apa yang dikerjakan itu dengan melihat metode yang digunakannya. Ada beberapa kelompok ilmu yang pertama kali memisahkan diri dari filsafat, seperti; berkembangnya ilmu-limu alamiah (natural sciences) dan ilmu-ilmu sosial (sosial sciences). 
Dari urain di atas, paling tidak dapat dipahami bahwa filsafat dan ilmu meskipun pada tinjauan historisnya sukar dipisahkan karena filsafat yang merupakan induk dari segala ilmu pengetahuan, akan tetapi dalam perkembangan antara filsafat dan ilmu perlu dibedakan sacara definisi. Hemat penulis, pemetaan definisi antara filsafat dan ilmu bukan berarti mecoba untuk memalingkan keberadaan filsafat sebagi induk dari segala pengetahuan. Melainkan pemetaaan definisi ilmu dan filsafat, dimaksudkan untuk menegaskan kembali terkait eksistensi filsafat dan ilmu. Oleh karena itulah, pada pembahasan kali ini, penulis akan menguraikan secara definisi antara filasat dan ilmu.

\section{Makna Filsafat}

Filsafat dalam bahasa Inggris, yaitu philosophy, adapun istilah filsafat berasal dari bahasa Yunani, yaitu philosophia, bersumber dari dua akar kata Philos (cinta), dan Sophos (kebijaksanaa, pengetahuan, keterampilan, pengalaman). Jadi, secara etimologi, filsafat berarti cinta kebijaksanaan atau kebenaran (love of wisdom). Sedangkan dalam bahasa Arab orang filosof disebut dengan failasuf (Amsal Bakhtiar, 2013). Bila merujuk definisi filsafat menurut para tokoh-tokoh filsafat seperti: Pertama, Plato (427-347 SM) menjelaskan bahwa filsafat adalah pengetahuan segala yang ada. Kedua, Aristoteles (384-322 SM) yang merupakan murid Plato menyakan filsafat adalah proses penyelidikan atas segala benda. Ketiga, Marcus Tullius (106-43 SM) mengatakan bahwa filsafat adalah pengetahuan tentang sesuatu yang maha agung dan usaha untuk mencapainya. Keempat, Al Farabi (wafat 950 M) yang merupakan filsuf terbesar dunia Islam sebelum Ibn Sina menyatakan filsafat adalah ilmu pengetahuan tentang alam yang maujud dan bertujuan menyelidiki hakekat yang sebenarnya. Hal senada juga dikemukakan oleh Harun nasution yang menjelasakan filsafat adalah berfikir menurut tata tertib (logika) dengan bebas (tak terkat tradisi, dogma dan agama) dan dengan sedalam-dalamnya sehingga sampai ke dasar-dasar persoalan (Sabri, 2009).

Dari penjelasan definisi filsafat yang dikemukakan oleh beberapa tokoh tersebut, menurut penulis bahwa filsafat pada inti menekankan 
tentang konsepsi pengetahuan yang ada di dalam diri manusia, yang mesti dipergunakan untuk mengetahui dan memahamin segala sesuatu yang ada di alam semesta, hingga muncul kesadaran pribadi tentang adanya pencipta dari segala yang ada ini. Dengan kata lain, filsafat dapat dimaknai sebagai proses pemurnian fikiran ke arah alam untuk mengenal dan mengetahui segalanya-segalanya.

\section{Makna Ilmu}

Ilmu berasal dari bahasa arab yakni 'alima, ya'lamu 'ilman dengan wajan fa'ila, yaf'alu yang artinya mengerti, memahami benarbenar. Dalam bahsa inggris disebut science; dari bahasa latin scientia yang artinya pengethuan atau mengetahui. Sedangkan pengertian ilmu yang terdapat kamus bahasa Indonesia adalah pengetahuan suatu bidang yang disusun secara bersistem menurut metode-metode tertentu, yang dapat digunakan untuk menerangkan gejala-gejala tertentu dibidang pengetahuan itu. Menurut beberapa para ahli, seperti yang diungkapkan oleh Karl Person, mengatakan ilmu adalah keterangan yang konperehensif dan konsisten tentang fakta pengalaman dengan istilah yang sederhana. Selanjutnya, menurut Muhammad Hatta, ilmu adalah pengetahuan yang teratur tentang pekerjaan hukum kausal dalam suatu golongan masalah yang sama tabiatnya, maupun kedudukannya tampak dari luar, maupun menurut bangunannya dari dalam. Kemudian Ashley Montagu, seorang guru besar antropolog di Rutgers University, menyimpulkan bahwa ilmu adalah pengetahuan yang disusun dalam satu sistem yang berasal dari pengamatan, studi dan percobaan untuk menentukan hakikat prinsip tentang hal yang sedang dikaji (Amsal Bakhtiar, 2013).

Dari beberapa keterangan di atas, dapat dipahami oleh penulis bahwa definisi tentang ilmu sebenarnya menekankan pada persoalan tentang ikhtiar penggunaan fikiran manusia secara sistematis dalam menelaah atau meneliti obyek tertentu, sehingga memberikan merberikan kesimpulan dan penjelasan, yang ahirnya dapat dijadikan sebagai landasan pengetahuan secara teoritis. 


\section{Pengertian Filsafat Ilmu}

Jika berbicara mengenai filsafat ilmu, kita sulit untuk memberikan batasan yang positif. Banyak pendapat yang memilki makna serta penekanan yang berbeda tentang filsafat ilmu. Sebagai contoh ialah perbedaan pendapat antara Stephen Toulmin dengan Ernest Nagel tentang apakah filsafat ilmu merupakan suatu studi scientific achievement in vivo atau studi tentang masalah-masalah mengenai penjelasan (problems of explanaton). Untuk menetapkan dasar pemahaman tentang filsafat ilmu sangat bermanfaat untuk menyimak tiga titik pandangan (view points) di dalam filsafat ilmu (Made Putrawan, 1999). Pandangan pertama menyebutkan filsafat ilmu adalah perumusan world-views yang kosisten dengan, dan pada beberapa pengertian didasarkan atas, teori-teori ilmiah yang penting. Menurut pandangan ini, merupakan tugas dari filsuf ilmu (philosopher of science) untuk mengkolaborasikan implikasi yang lebih luas dari ilmu. Pandangan kedua mengemukakan bahwa filsafat ilmu adalah suatu eksposisi dari presuppositions dan predispositions dari para ilmuwan. Filsuf ilmu mungkin mengemukakan bahwa para ilmuwan menduga (presuppose) alam tidak berubah-ubah, dan terdapat suatu keteraturan di alam sehingga gejala-gejala alam yang tidak begitu kompleks cukup didapat oleh peniliti. Sebagai tambahan, peneliti mungkin tidak menutup keinginan-keinginan deterministik para ilmuwan lebih daripada hukumhukum statistik, atau pandangan mekanistik lebih daripada penjelasan teleologis. Pandangan ini cenderung mengasimilasikan filsafat ilmu dengan sosiologi.

Pandangan ketiga mengemukakan bahwa filsafat ilmu itu adalah suatu disiplin yang di dalamnya konsep-konsep dan teori-teori tentang ilmu yang dianalisis dan diklasifikasikan. Hal ini berarti memberikan kejelasan tentang makna dari berbagai konsep seperti partikel, gelombang, potensial, dan komplek di dalam pemanfaatan ilmiahnya. Akan tetapi, Gilbert Ryle telah menunjukan terdapat sesuatu yang pretensius (pretentious) tentang pandangan ini mengenai filsafat ilmu sehingga para ilmuwan memerlukan filsafat ilmu untuk menjelaskan 
kepada mereka makna dari konsep-konsep ilmiah. Oleh karena itu, ada dua kemungkinan. Apakah para ilmuwan benar-benar mengerti suatu konsep yang digunakannya sehingga dalam kasus ini tidak lagi memerlukan klasifikasi, atau ilmuwan itu tidak tahu makna konsep tersebut sehingga mereka harus mencari (inquiry) hubungan konsep itu dengan konsep-konsep lain dan dengan operasi pengukuran.

Inkuiri tersebut merupakan suatu kegiatan ilmiah yang tipikal. Tak seorang pun akan menuntut bahwa setiap kali seorang ilmuwan inkuari itu, ia sedang mempraktekan flsafat ilmu. Demikian juga, tidak setiap analisis konsep-konsep ilmiah dikualifikasikan sebagai filsafat ilmu. Akan tetapi, tipe analisis konseptual yang tertentu hendaknya diklasifikasikan sebagai bagian dari filsafat ilmu (Made Putrawan, 1999). Menegaskan pandangan di atas, bahwa ada beberapa tokoh yang menjelaskan pengertian filsafat ilmu, antara lain:

1. Menurut A. Cornelius Benjamin filsafat ilmu merupakan cabang pengetahuan filsafat yang merupakan telaah sistematis mengenai ilmu, khususnya metode-metodenya, konsep-konsepnya dan praanggapan-praanggapan, serta letaknya dalam kerangka umum cabang-cabang pengetahuan intelektual.

2. Lewis White Beck, memberi pengertian bahwa filsafat ilmu membahas dan mengevaluasi metode-metode pemikiran ilmiah serta mencoba menemukan dan pentingnya upaya ilmiah sebagai suatu keseluruhan.

3. Michael V. Berry berpendapat bahwa filsafat ilmu adalah penelaahan tentang logika interen dari teori-teori ilmiah dan hubungan-hubungan antara percobaan dan teori, yakni tentang metode ilmiah.

4. Menurut May Brodbeck filsafat ilmu adalah analisis yang netral secara etis dan filsafati, pelukisan dan penjelasan mengenai landasanlandasan ilmu (Salwinsah, 2013).

Penjelasan di atas, dalam hemat penulis terdapat beberapa poin penting yang mesti dipahami terkait pengertian atau batasan filsafat ilmu, antara lain: 1) Pandangan tentang filsafat ilmu seperti yang telah uraikan, pada dasarnya menekankan bahwa filsafat ilmu itu sebagai proses ilmiah secara sistematis yang dilakukan oleh filsuf atau peneliti 
untuk mengungkapkan dan mengklasifikasikan tentang obyek-obyek pengetahuan tertentu. 2) Pengetian filasat ilmu meskipun berbeda, akan tetapi dari sisi substansi hampir memiliki muatan yang sama, yakni menempatkan filasat ilmu sebagai bentuk ikhtiar manusia. 3) Untuk menegaskan tentang pengertian filasat ilmu, perlunya memahami batasan antara filsafat dan ilmu sebagai parameter untuk menjelaskan kedudukan filasafat ilmu.

\section{Obyek Telaah Filsafat IImu}

Karena kompleksnya ilmu pengetahuan dalam tradisi manusia, maka cakupan filsafat ilmu dengan sendirinya sangat luas dan mencakup persoalan konsep yang erat kaitannya dengan ilmu itu sendiri, sehingga pemecahannya dapat dipandang sebagai suatu sumbangan kepada ilmu pengetahuan (Sabri, 2009). Pada dasarnya, ilmu memiliki dua macam obyek penelaahannya, yaitu obyek material dan obyek formal. Objek material adalah sesuatu yang dijadikan sasaran penyelidikan, seperti tubuh manusia adalah obyek material ilmu kedokteran. Adapun obyek formal adalah metode untuk memahami obyek material tesebut, seperti penekanan induktif dan deduktif. Di astu sisi, filsafat juga memilki obyek material dan obyek formal. Obyek material filsafat adalah segala yang ada. Segala yang ada mencakup ada yang tampak dan ada yang tidak tampak. Ada yang tampak adalah dunia emperis, sedangkan ada yang tidak nampak adalah alam metafisik. Sebagian filosof membagi obyek material filsafat atas tiga bagian, yaitu yang ada dalam emperis, yang ada dalam pikiran, dan yang ada dalam kemungkin. Adapun, obyek formal filsafat adalah sudut pandang yang menyeluruh, radikal, dan rasional tentang segala yang ada (Amsal Bakhtiar, 2013).

Cakupan obyek filsafat lebih luas dibandingkan ilmu, karena ilmu hanya terbatas pada persoalan empiris saja, sedangakn filsafat mencakup yang empiris dan yang non empiris. Tidak bisa dipungkiri, bahwa secara historis ilmu berasal dari kajian filsafat karena awalnya filsafatlah yang melakukan pembahasan dari segala yang ada ini dengan sistematis, rasional dan logis, termaksud hal yang empiris. Sehingga filsafat dalam pandangan para filosof adalah induk dari segala ilmu. Sebab, dari 
filsafatlah, ilmu modern dan kontemporer berkembang, dan akhirnya generasi manusia pada masa sekarang maupun yang akan datang dapat menikmati buahnya, seperti teknologi dan lain sebagainya (Amsal Bakhtiar, 2013).

Menurut hemat penulis, sebagai penegasannya ada beberapa muatan penting terkait dengan obyek telaah filsafat ilmu, antara lain: Pertama, obyek telaah Filsafat ilmu, hakikatnya menekankan pada persoalan obyek materi dan formal. Obyek materi yang adalah proses penyelidikan fakta empiris, sedangkan obyek formalnya menegaskan pada persoalan upaya atau cara untuk memahami hal-hal yang sifatnya materi. Kedua, meskipun filsafat dan ilmu, obyek telaahnya kendati muatanya sama, akan tetapi terdapat perbedaan pada cakupan keluasannya. Misalkan filsafat pada obyek materinya mekankan dua hal yang mendasar meliputi empiris dan non empiris. Sedangkan dalam ilmu, obyek materinya hanya memenuhi aspek empiris. Ketiga, rentetan perkembangan bidang-bidang ilmu pengetahuan yang semakin lama semakin terspealisasi, mengindikasikan bahwa obyek penelaahan filsafat ilmu bersifat komleks dan bukan sesuatu yang mutlak, dengan kata lain tidak kata final dalam mengkaji dan mengembangkan keilmuan.

\section{SIMPULAN}

Berangkat dari beberapa uraian sebelumnya kaitanya dengan pembahasan tentang pengertian dan obyek telaah filsafat ilmu, maka dapat disimpulkan antara lain: 1) Pengertian filsafat ilmu bisa dilandaskan pada batasan antara filsafat dan ilmu, sehingga akhirnya dapat diintegrasikan dalam cara pandang pengertian filsafat ilmu secara umum. Sedangkan dalam hemat penulis sendiri, bahwa Filsafat ilmu dapat diartikan sebagai konsepsi secara teoritis dan merupakan hasil dari proses ilmiah yang sistematis, untuk menjelaskan maupun mengungkapkan tentang sesuatu, terkait dengan obyek-obyek pengetahuan. 2) Obyek telaah Filsafat ilmu, hakikatnya menekankan pada persoalan obyek materi dan formal. Obyek materi yang dimaksud adalah proses penyelidikan fakta-fakta empiris, sedangkan obyek 
formalnya menegaskan pada persoalan upaya atau cara untuk memahami hal-hal yang sifatnya materi.

\section{DAFTAR PUSTAKA}

Bakhtiar, Amsal. 2013. Filsafat Ilmu. Jakarta: PT Rajagrafindo persada.

Peursen, C.A.Van. 1989. De Opbouw Van De Wetenschap Een Inleiding In De Wetenschapsleer, terj. J. Drost, Susunan Ilmu Pengetahuan Sebuah Pengantar Filsafat Ilmu. Jakarta: PT Gramedia.

Putrawan, I. Made dkk. 1999. Dimensi Kreatif Dalam Filsafat ilmu. Bandung: PT Remaja Rosdakarya..

Salwinsah. 2013. "Pengertian dan Ruang Lingkup Filsafat Ilmu",http://salwintt.wordpress.com/artikel/kisah-islami/pengertiandan-ruang-lingkup-filsafat-ilmu/ .

Setiawan, Conny dkk. 2005. Penorama Filsafat Ilmu Landasan Perkembangan Ilmu Sepanjang Zaman. Jakarta: PT Mizan Publika.

Sabri, Muhammad dkk.2009. Filsafat Ilmu. Cet. I; Makassar: Alauddin Pers.

Zubair, Achmad Charris. 2002. Dimensi Etik dan Estetika Ilmu Pengethuan Manusia Kajian Filsafat Ilmu. Yogyakarta: LESFI. 